\author{
Dario Šimičević, PhD, Snežana Štetić, PhD \\ College of tourism, Belgrade \\ UDC 338.488.2:640.4(497.11 Београд) \\ 338.48-44(497.11-21)
}

\title{
CHANGES IN HOTEL OFFER OF BELGRADE DRIVEN BY TOURIST DEMAND
}

\begin{abstract}
This paper focuses on changes that have been noticed in hotel offer of Belgrade during first decade of 21st century. It will be shown that these changes are associated with characteristics of tourism demand, reason of tourists visit and their behavior during the stay. Changes are expressed not only in the rise of number of beds but also in the structural changes of hotel offer in Belgrade. As one of major destinations in Serbia which attracts the majority of foreign and a great deal of domestic guests, Belgrade had to change hotel offer quantitatively as well as qualitatively. Also, this paper will focus on
\end{abstract}

\section{Introduction}

Hotels and hotel accommodation represent a major asset in the development of urban tourist destinations. Big urban centers as multifunctional tourist destinations attract various types of tourists according to the purpose of their visit (Šimičević, 2011). Belgrade, the biggest urban destination in Serbia which attracts $30 \%$ of overall tourists in Serbia and $60 \%$ of foreign tourists in Serbia, needs to develop hotel accommodation in order to meet tourists' needs. Compared to 300 million international tourist arrivals in European cities in 2008 (Jerković, 2009) Belgrade participates with only $0.14 \%$ in the distribution of urban tourists in Europe.

Hotels in urban tourist destinations, in order to increase profit and gain better competitive position on the market, evolved the influence of business tourism development on hotel offer. Business tourism is in tight relationship with changes identified and presented in this paper. Business tourists present a major group of tourists in Belgrade and it is expected to remain so in the following years. The strategy of tourism development of Belgrade and developing of tourism investments back up these statements that will be shown in this paper.

Key words: hotel industry, tourism, tourist destination, Belgrade, Serbia

from board and lodging facilities to most complex organizations which provide convention services and venues (Šimičević, 2009). According to some definitions hotels are considered as convention centers if they are permanently equipped with technology necessary for meetings, with enough space for 50 participants and if they promote this activity on the market (Bernini, 2009). When it comes to organization of business events, hotels often represents the most attractive part of the overall product for the participants (Davidson and Cope, 2003).

Some assessments show that major segment among tourists in Belgrade are business tourists and they participate with $50 \%$ to $60 \%$ in overall number of tourists in Belgrade. More detailed data will be shown in this paper. So, it is quite proper to assume that the present structure of tourists in Bel- 
grade is in correlation with the development of hotels in Belgrade. Hotel accommodation in Belgrade has experienced changes which have been partially driven by tourist demand needs and partially by trends present in hotel sector in the world. Since the majority of tourists in Belgrade are business tourists, Belgrade hotels are designed and they are developing their business in order to attract as many business tourists as possible and in that way to achieve greater market share in this segment. More accurate data concerning number of rooms and seats in meeting capacity are going to be presented later in the paper. This will strengthen the position of Belgrade as a business tourism destination on the European market and especially on the market of the South Eastern Europe in the following years. Also, it will influence the future development of Belgrade tourist product and we can presume that business tourists will be a dominant segment in following midterm period. More precise data and explanations are going to be presented in this paper.

\section{The state of hotel industry in Serbia}

In last two decades numerous changes have occured in the structure and purpose of hotels in Serbia. In that respect it is possible to identify three stages in the development of accommodation in Serbia. The first stage was present until 1990, accompanying development of Belgrade as important convention and congress center (Štetić, 2007), the second stage includes the period between 1990 and 2000 and the third stage is present since 2001 till nowadays with special accent on the period after 2005 when fast changes have occurred inside hotel industry.
In the period covered by the first stage in the development of accommodation in Serbia a significant growth of accommodation was recorded, especially in the period between 1970 and 1980 when number of beds rose from 74.000 beds in 1970 to 108.000 beds in 1980. ${ }^{1}$ After that follows a calm period which is characterized by the slow enhancement of overall number of beds in accommodation in Serbia (only 7941 beds in ten years or fewer than 1.000 per year). A positive thing in this ten-year period is that hotel accommodation recorded the biggest development with 11.000 new beds or 30\% more than in 1980 (Statistical Yearbook of Serbia-2000). However, the second stage which covers the period between 1990 and 2000 was characterized by a significant drop in accommodation under the influence of negative economic, political and security environment which affected tourism in terms of stopping the investments, degrading and closing some accommodations. During that stage the number of beds in accommodation in Serbia dropped from 116.000 to 92.000 beds. After 2000 comes the third stage with more stable economic and political environment. Nevertheless the first half of the first decade in 21 st century was not very promising for the accommodation sector in Serbia. In 2003 the number of beds in accommodation sector of Serbia recorded its minimum in last 35 years with only 85.634 beds in all accommodation. But, after 2005 comes a better period with fast recovery of accommodation sector and the number of beds in 2009 reached 112.815 beds in all accommodation and this slightly slipped down to 107.256 in 2013. Graph 1 shows the number of beds in Serbia in 21st century.

In this ten-year period hotel accommodation rose for $115 \%$ and the number of beds rose from 12.000 to over 26.000. Despite this hotel accommodation participated less than $25 \%$ in overall accommodation in Serbia. 
Graph 1. Number of beds in Serbia by type of tourist destination

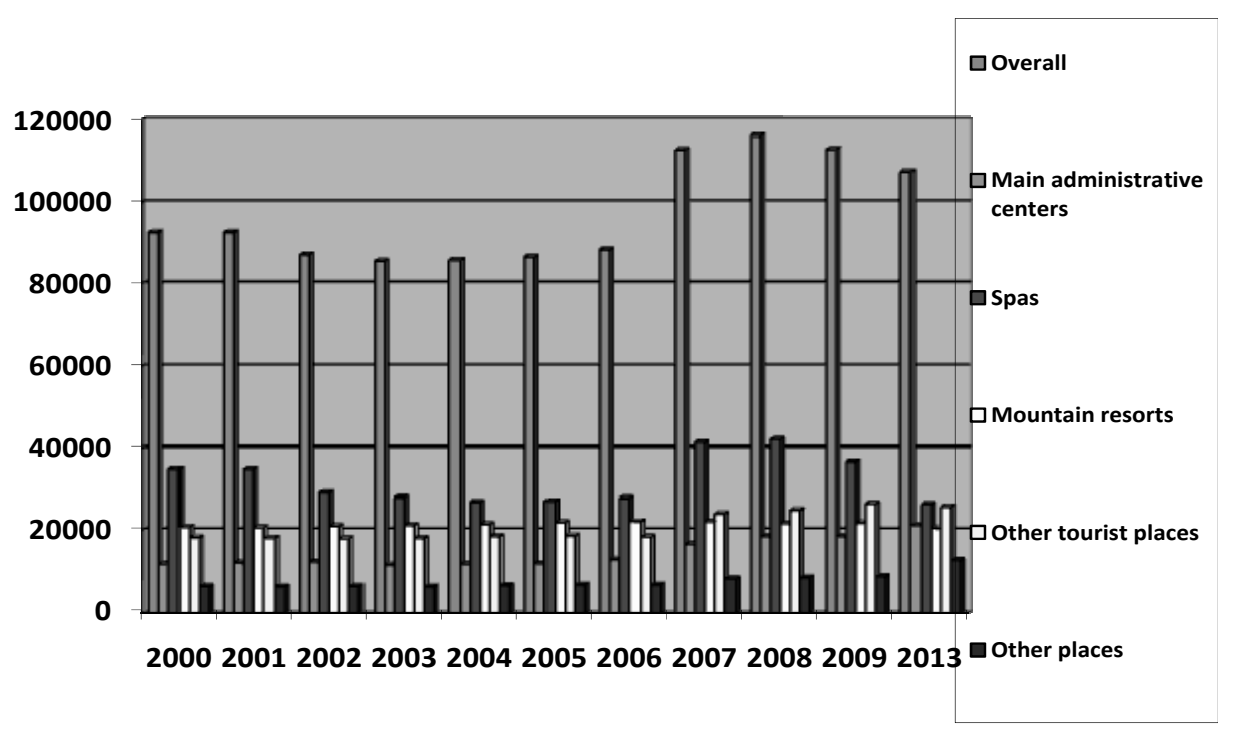

Source: Statistical Yearbooks of Serbia 2000-2014.

In hotel accommodation in Serbia, domestic and foreign tourists spend $43.23 \%$ of nights in all accommodation. This information indicates that hotel accommodation in Serbia has a dominant and driving position in overall development of tourism in Serbia. Considering hotel sector in Serbia majority of nights tourists spend in 2 and 3- star hotels and after them in 4- star hotels. Hotels with the lowest number of nights spent by tourists are those with 1 and 5 stars. This is totally in accordance with overall structure of hotel accommodation in Serbia consider- ing that majority of hotels are those with 2, 3 and 4 stars. There is a slight trend of changing structure of hotel accommodation in favor of hotels with 4 and 5 stars. However, hotels with 4 and 5 stars are mainly present in already developed destinations as Belgrade and Novi Sad. This segment of hotel offer together with well equipped 3 star hotels are the basis for the development of urban destinations and business tourism. Following this it is expected that future development of hotel offer continues this way. 
Table 1. Number of nights tourists spent in Serbia by accommodation type (in 000)

\begin{tabular}{|l|c|c|c|c|c|c|c|c|c|}
\hline \multirow{2}{*}{$\begin{array}{l}\text { Accommodation } \\
\text { by type }\end{array}$} & \multicolumn{9}{|c|}{ Year } \\
\cline { 2 - 11 } & $\mathbf{2 0 0 2}$ & $\mathbf{2 0 0 3}$ & $\mathbf{2 0 0 4}$ & $\mathbf{2 0 0 5}$ & $\mathbf{2 0 0 6}$ & $\mathbf{2 0 0 7}$ & $\mathbf{2 0 0 8}$ & $\mathbf{2 0 0 9}$ & $\mathbf{2 0 1 3}$ \\
\hline Hotels & $\mathbf{3 7 6 9}$ & $\mathbf{3 4 7 7}$ & $\mathbf{3 4 9 4}$ & $\mathbf{3 4 8 4}$ & $\mathbf{3 4 3 0}$ & $\mathbf{3 6 1 2}$ & $\mathbf{3 6 9 0}$ & $\mathbf{3 1 7 2}$ & $\mathbf{2 8 3 9}$ \\
\hline $5^{*}$ hotels & 159 & 145 & 125 & 161 & 189 & 219 & 195 & 212 & 207 \\
\hline $4^{*}$ hotels & 388 & 1382 & 342 & 348 & 391 & 551 & 569 & 530 & 962 \\
\hline $3^{*}$ hotels & 1943 & 1780 & 1379 & 1321 & 1289 & 1453 & 1435 & 1207 & 882 \\
\hline $2^{*}$ hotels & 827 & 768 & 1158 & 1205 & 1102 & 924 & 1017 & 830 & 659 \\
\hline $1^{*}$ hotels & 81 & 121 & 218 & 171 & 170 & 188 & 161 & 102 & 129 \\
\hline Uncategorized & 371 & 281 & 272 & 278 & 289 & 277 & 313 & 291 & $/$ \\
\hline Other & $\mathbf{6 6 7}$ & $\mathbf{5 9 8}$ & $\mathbf{6 7 1}$ & $\mathbf{6 5 2}$ & $\mathbf{6 4 9}$ & $\mathbf{8 7 2}$ & $\mathbf{7 8 7}$ & $\mathbf{8 0 9}$ & $\mathbf{5 9 8}$ \\
\hline $\begin{array}{l}\text { Complementary } \\
\text { accommodation }\end{array}$ & $\mathbf{2 7 7 1}$ & $\mathbf{2 6 1 0}$ & $\mathbf{2 4 7 8}$ & $\mathbf{2 3 6 3}$ & $\mathbf{2 5 1 3}$ & $\mathbf{2 8 4 5}$ & $\mathbf{2 8 5 7}$ & $\mathbf{2 7 8 1}$ & $\mathbf{3 1 2 8}$ \\
\hline Overall & $\mathbf{7 2 0 7}$ & $\mathbf{6 6 8 5}$ & $\mathbf{6 6 4 3}$ & $\mathbf{6 4 9 9}$ & $\mathbf{6 5 9 2}$ & $\mathbf{7 3 2 9}$ & $\mathbf{7 3 3 4}$ & $\mathbf{6 7 6 2}$ & $\mathbf{6 5 6 7}$ \\
\hline
\end{tabular}

Source: Statistical Yearbooks of Serbia 2003-2014.

Table 2 shows structure of hotel accommodation in Serbia in 2006 and 2011. The data presented in this table shows that structural changes happened inside hotel accommodation in Serbia. These changes are positive because the participation of hotels with 4 and 5 stars increased from $11.8 \%$ in 2006 to $22.3 \%$ in 2011 or it is doubled. This change is in accordance with needs and expectations of business tourists and presents a positive step in the development of hotel offer in Serbia. Major factors driving these changes are the construction of new hotels and partial reconstruction of existing ones. Major disadvantage accompanying these processes is that the hotel construction is concentrated in already developed tourist and business centers as Belgrade and Novi Sad while other parts of Serbia are neglected (except some spa destinations).

Table 2. Hotel structure in Serbia by category (in \%)

\begin{tabular}{|c|c|c|c|}
\hline Hotels by category & Year & 2006. & March 2011. \\
\hline Overall & & 100 & 100 \\
\hline $5^{*}$ hotels & & 2,8 & 4,0 \\
\hline $4^{*}$ hotels & & 9,0 & 18,3 \\
\hline $3^{\star}$ hotels & & 32,8 & 34,5 \\
\hline $2^{\star}$ hotels & & 42,7 & 32,9 \\
\hline $1^{*}$ hotels & & 12,7 & 10,3 \\
\hline
\end{tabular}

Source: www.turizam.merr.gov.rs and Kosar Lj. (2008): Obim i struktura hotelijerstva Srbije u kontekstu budućeg razvoja, Conference Proceedings - Hotelska kuća 2008, Zlatibor, pp. 61-72.

International hotel chains are the most significant factor in the future development of business tourism in Serbia. At this moment 8 international hotel chains oper- ate in Serbia (Hotel Guide, Hores, 2015) and even more should open their hotels in 2015. Stronger presence of international hotel chains should influence rising of quality 
and quantity of services in hotel and other sectors, improvement of destination product of Serbia, its position in international tourist market and attraction of larger number of events and business tourists. This should affect overall tourist and economic development of Serbia.

\section{Characteristics of Belgrade visitors}

Belgrade as a leading tourist destination in Serbia represents the major point of inter- est for many tourists. In 2013 around 31\% (718.943) of overall tourists in Serbia visited Belgrade. In the same year foreign tourists who visited Belgrade represented 58.25\% of all foreign tourists in Serbia. Domestic tourists are more evenly distributed across the Serbia and domestic tourists in Belgrade participated with $14.32 \%$ of all domestic tourists in Serbia. At the same time participation of tourist nights spent in Belgrade in overall nights spent in Serbia is around $23 \%$. Foreign tourists achieved $69.56 \%$ of all nights tourists spent in Belgrade.

Table 3. Number of visitors and nights spent in Belgrade

\begin{tabular}{|c|c|c|c|c|c|c|}
\hline \multirow{2}{*}{ Year } & \multicolumn{3}{|c|}{ Arrivals } & \multicolumn{3}{c|}{ Nights } \\
\cline { 2 - 7 } & Overall & Domestic & Foreign & Overall & Domestic & Foreign \\
\hline $\mathbf{2 0 0 2}$ & 788.904 & 598.024 & 190.880 & 1.498 .352 & 1.062 .541 & 435.811 \\
\hline $\mathbf{2 0 0 3}$ & 728.087 & 513.978 & 214.109 & 1.360 .934 & 891.412 & 469.522 \\
\hline $\mathbf{2 0 0 4}$ & 692.933 & 449.694 & 243.239 & 1.384 .389 & 871.338 & 513.051 \\
\hline $\mathbf{2 0 0 5}$ & 674.785 & 397.677 & 277.108 & 1.183 .000 & 592.417 & 590.583 \\
\hline $\mathbf{2 0 0 6}$ & 705.439 & 424.471 & 280.968 & 1.366 .429 & 794.295 & 532.134 \\
\hline $\mathbf{2 0 0 7}$ & 764.466 & 328.528 & 435.938 & 1.563 .526 & 701.405 & 862.121 \\
\hline $\mathbf{2 0 0 8}$ & 705.574 & 328.657 & 376.917 & 1.431 .328 & 671.485 & 759.843 \\
\hline $\mathbf{2 0 0 9}$ & 602.034 & 232.457 & 369.577 & 1.368 .842 & 540.112 & 828.730 \\
\hline $\mathbf{2 0 1 0}$ & 618.454 & 223.046 & 395.408 & 1.319 .629 & 509.807 & 809.822 \\
\hline $\mathbf{2 0 1 3}$ & 718.943 & 182.006 & 536.937 & 1.489 .801 & 453.526 & 1.036 .275 \\
\hline
\end{tabular}

Source: Statistical Yearbooks of Serbia 2002-2014 and https://zis.beograd.gov.rs

Through the analysis of the number of tourists in Belgrade and the nights they spent in Belgrade (Table 3) in the 21st century, two trends are obvious. The first trend is a constant decrease in the number of domestic tourists in Belgrade through the whole period observed. The number of domestic tourists decreased by $69.5 \%$ from 598 thousand to 182 thousand with further negative trends in 2014. The decreasing number of domestic tourists strongly influenced the number of nights they spent in Belgrade which was more than halved in this period. The second trend is the constant increase in the number of foreign tourists in Belgrade. Their number rose by $280 \%$, from 190 thousand in 2002 to 536 thousand in 2013, with even better results in 2014. The accompanying consequence of this is the increase in the number of the nights spent in Belgrade by $130 \%$ with, also, better results in 2014 .

The great number of tourists among foreign tourists are from the former Yugoslav states and they participate in the overall number of foreign tourists in Belgrade in 2010 with $38.12 \%$ which makes 150.757 tourists. Besides them, tourists from other neighboring countries (Hungary, Romania, 
Bulgaria, Greece, Italy and Austria) participate with $21.44 \%$ which all together means that tourists from surrounding countries make $59.56 \%$ of all foreign tourists in Bel- grade. This fact shows us that Belgrade has a very limited market which is not very familiar to more distant markets. (Graph 2)

Graph 2. Foreign tourists in Belgrade

by country of origin in 2010.

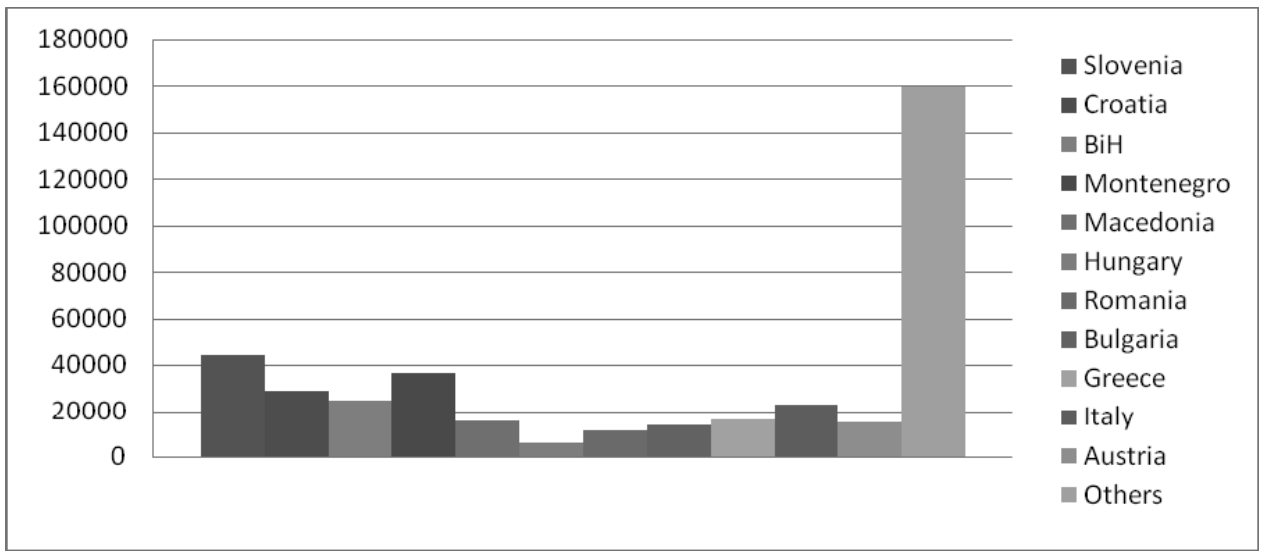

Source: https://zis.beograd.gov.rs

There is no complete and accurate information about the purpose of the visit of tourists to Belgrade. The all information available is based on calculations, assessment and partial surveys. The available information is incomplete for several reasons. The first is that the statistical data provided by accommodation providers is not accurate. Even though modern hotel business includes programs for management of hotel operations and statistical packages for statistical processing, hotel managers in Belgrade often instruct employees to select all guests as business guests because they are their primary market. So, data provided by them are not accurate. Also, there is not one planed and constant statistical effort which will provide accurate and up to date data and strategic base for further actions in serving customer needs.
The available data shows to us that business guests are most numerous guests in Belgrade. This fact is not a surprise because Belgrade as an economic, cultural and administrative center of the country is the major destination of business tourism and tourism in general in Serbia. The strategy of tourism of Belgrade shows us that business tourists in Belgrade make around 65.59\% of total nights tourists spend in Belgrade (Graph 3). These figures are in line with one of our surveys conducted in 2009 in 10 Belgrade hotels on 290 guests that showed that $58 \%$ of foreign guests stay in Belgrade for business reasons. The survey was conducted only among foreign guests but it can be presumed that the result would not be much different if domestic guests were included. It can be said that $60 \%$ presents realistic information about participation of business tourists in overall number of tourists. 
Graph 3. Tourists in Belgrade by purpose of visit in 2006 and the assessment for 2018 (tourist stays in \%)

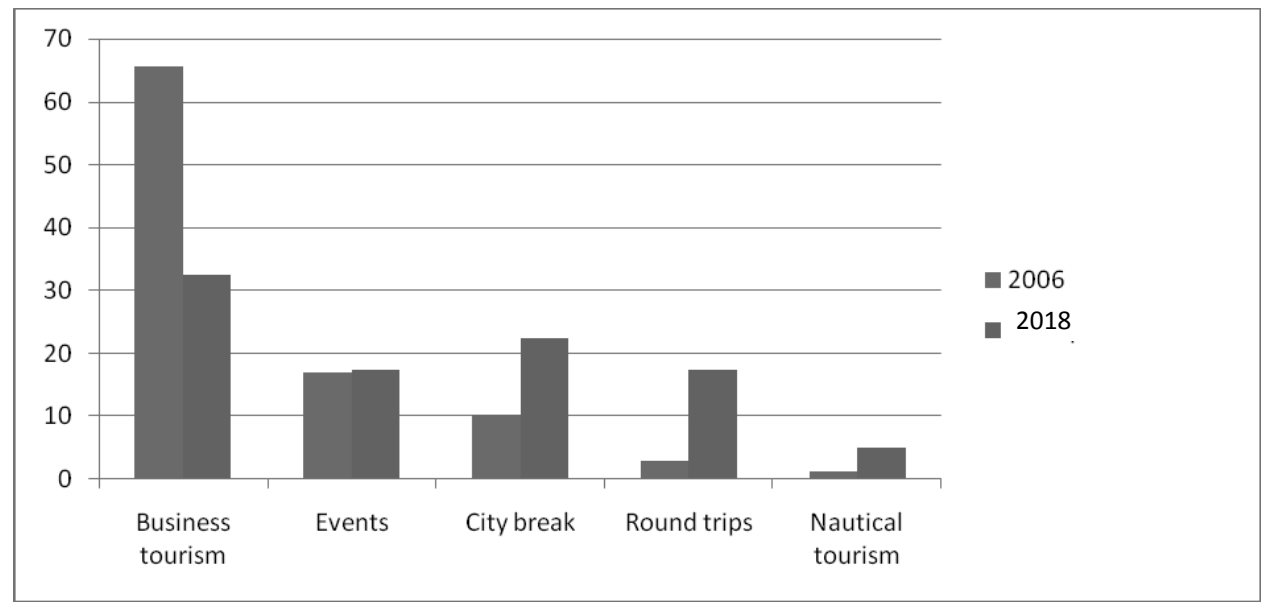

Source: Strategy of tourism development of Belgrade (2008), Institute of economic sciences, Belgrade, p. 245.

We think that the Strategy of tourism development of Belgrade is oversized when it comes to the number of tourists in Belgrade in 2018. It predicts 4 million tourist stays in Belgrade in 2018 in its moderate prediction. Considering the fact that in 2011 in Belgrade visitors made around 1.2 million nights what is less than in 2006 it is not to be expected that in the following years they can almost quadruple the number of stays.
If we add to previous calculations, predictions and surveys data provided by the International Congress and Convention Association (ICCA) it can be concluded that Belgrade have been developed as a leading business tourism destination in South Eastern Europe. By ICCA data ${ }^{2}$ Belgrade now is the fastest growing destination in Eastern Europe in terms of international conventions occurring and it is positioned right below regional leaders Vienna, Budapest and Prague.

Table 4. Number of meetings in Belgrade based on ICCA data

\begin{tabular}{|l|c|c|c|c|c|c|c|}
\hline Year & 2005 & 2006 & 2007 & 2008 & 2009 & 2010 & 2014 \\
\hline Number of meetings & 11 & 8 & 12 & 16 & 25 & 33 & 50 \\
\hline
\end{tabular}

Source: The International Association Meetings Market 2000-2009 (2010), International Congress and Convention Association (ICCA), Amsterdam, The International Association Meetings Market 2014, International Congress and Convention Association (ICCA), Amsterdam. and www.scb.travel.

2 The ICCA data are based on the ICCA Association Database, which means the figures cover meetings organized by international associations which take place on a regular basis and which rotate between a minimum of three countries. 
After quick overview on characteristics of Belgrade visitors it may be concluded that the hotel offer in Belgrade experienced changes which are influenced by requests and needs of guests visiting Belgrade on one hand, but also which have been influencing the profile of visitors in Belgrade and modes of tourism development in Belgrade. In next chapter we will show the character and speed of changes inside hotel industry in Belgrade in 21 st century.

\section{Changes in hotel offer of Belgrade}

Belgrade as tourist destination has experienced numerous changes in last decade. Some of most visible changes occurred inside hotel sector. These changes happened in qualitative and quantitative aspects of hotel business in Belgrade and they can be observed from several standpoints. The first aspect is speed of changes in terms of the number of hotels developed in last decade. The development of hotel accommodation in Belgrade in last ten years is dynamic and includes domestic and foreign investors. This is good because it will influence the quality and diversity of hotel offer in Belgrade.

Table 5. Changes in number of hotels in Belgrade

\begin{tabular}{|l|c|c|c|c|c|c|}
\hline Year & $\mathbf{2 0 0 6}$ & $\mathbf{2 0 0 7}$ & $\mathbf{2 0 0 8}$ & $\mathbf{2 0 1 0}$ & $\mathbf{2 0 1 1}$ & $\mathbf{2 0 1 5}$ \\
\hline Number of hotels & 43 & 45 & 47 & 52 & 54 & 81 \\
\hline
\end{tabular}

Source: Statistical Yearbook of Belgrade 2013 and www.tob.co.rs.

When it comes to the structure of hotels in Belgrade the largest number of hotels are those with 3 and 4 stars which together participate with $67 \%$ in overall number of hotels (23 hotels with 3 stars and 33 hotels with 4 stars). Hotels with 4 and 5 stars participate with $44.4 \%$. These facts correspond with characteristics and needs of visitors in Belgrade (business visitors). That means that hotels with 3, 4 and 5 stars make $72.83 \%$ of hotels in Belgrade. This is much higher than in Serbia and we can conclude that one of major factors influencing this is the type of visitors in Belgrade.

At the moment 8 international hotel chains operate in Belgrade: Global Hyatt Corporation, InterContinental Hotels Group, Best Western International, The
Golden Tulip, Marriott International, Rezidor Hotel Group, Falkensteiner Hotels \& Residences and Classical Hotels. It is interesting that almost all new and renovated hotels in Belgrade emphasize business tourists as their major or one of the major segments on the market. Accordingly these hotels develop their own conference and convention capabilities and venues which can welcome from several dozens to several hundreds of participants at the same time. It is in line with a worldwide trend of high concentration of convention supply in the hotel sector as a strategy which integrates traditional tourism supply with convention services in order to maintain constant activity throughout the year and to improve economic performance (Bernini, 2009). 
Table 6. Already operating and planed hotels as members of international hotel chains

\begin{tabular}{|l|l|l|}
\hline $\begin{array}{l}\text { International hotel chain } \\
\text { (ITC) }\end{array}$ & $\begin{array}{l}\text { Hotels as members of ITC } \\
\text { already operating in Belgrade }\end{array}$ & $\begin{array}{l}\text { Planed ITC hotels in Belgrade } \\
\text { in 2016 and 2017 }\end{array}$ \\
\hline Global Hyatt Corporation & Hyatt Regency Belgrade & \\
\hline InterContinental Hotels Group & $\begin{array}{l}\text { Holiday Inn Belgrade } \\
\text { Crown Plaza Beograd } \\
\text { Holiday Inn Express Beograd }\end{array}$ & $\begin{array}{l}\text { Best Western M } \\
\text { Best Western Šumadija }\end{array}$ \\
\hline Best Western International & Tulip In Putnik & \\
\hline The Golden Tulip & Courtyard by Marriott & \\
\hline Marriott International & Radison Blu Old Mill & \\
\hline Rezidor Hotel Group & Falkensteiner Novi Beograd & \\
\hline $\begin{array}{l}\text { Falkensteiner Hotels \& } \\
\text { Residences }\end{array}$ & Metropol Palace & Hilton Belgrade \\
\hline Classical Hotels & & \\
\hline Hilton Hotels \& Resorts & Source: Authors research & \\
\hline
\end{tabular}

Source: Authors' research

In order to measure convention and conference supply and capability of Belgrade hotels we propose using both the number of convention rooms and the number of seat places available for conferences and meetings within these hotels. The number of seat places is particularly useful in estimating the size of convention supply, but also in evaluating the possible types of events and meetings. For this purpose we used latest data provided by Serbian Convention Bureau and Belgrade Convention Bureau. (Table 7)

Table 7. Number of convention rooms and seat places in major business oriented Belgrade hotels

\begin{tabular}{|l|l|l|l|}
\hline Hotel & $\begin{array}{l}\text { Number of } \\
\text { convention rooms }\end{array}$ & $\begin{array}{l}\text { Number of seat } \\
\text { places }\end{array}$ & $\begin{array}{l}\text { Number of seat } \\
\text { places in largest } \\
\text { convention room* }\end{array}$ \\
\hline Hyatt Regency & 8 & 958 & 600 \\
\hline Continental & 9 & 880 & 600 \\
\hline Holiday Inn & 7 & 215 & 180 \\
\hline In Hotel & 5 & 225 & 90 \\
\hline Best Western M & 8 & 1520 & 600 \\
\hline Best Western Šumadija & 5 & 595 & 125 \\
\hline Falkensteiner & 9 & 800 & 300 \\
\hline Radisson Blu Old Mill & 6 & 412 & 220 \\
\hline Zira & 3 & 300 & 300 \\
\hline Moskva & 5 & 390 & 250 \\
\hline Balkan & 4 & 200 & 155 \\
\hline Belgrade Art Hotel - BAH & 3 & 170 & 70 \\
\hline
\end{tabular}




\begin{tabular}{|l|l|l|l|}
\hline Majestic & 2 & 130 & 90 \\
\hline Crystal & 1 & 80 & 80 \\
\hline Nevski & 1 & 60 & 60 \\
\hline Zlatnik & 1 & 45 & 45 \\
\hline TownHouse 27 & 1 & 20 & 20 \\
\hline Life Design Hotel & 1 & 50 & 50 \\
\hline Square Nine & 1 & 20 & 20 \\
\hline Overall & $\mathbf{8 0}$ & $\mathbf{7 0 7 0}$ & $\mathbf{6 0 0}$ \\
\hline
\end{tabular}

* joint rooms are taken in count

Source: Serbia meeting planner's guide 2011 (2011), Serbia Convention Bureau, Belgrade and Meetings and Conventions - Planner's Guide 2009/10 (2010), Belgrade Convention Bureau - Tourist organization of Belgrade, Belgrade. and www.scb.travel

Meeting and convention capacity of hotels in Belgrade present a significant addition to overall convention and meeting venues. With 7.000 seats in 80 meeting rooms with 600 seats in largest rooms in just 19 hotels, that convention bureau of Belgrade and Serbia represent in their planner guides, Belgrade hotels are able to host different kinds of business events, from business and company meetings to larger plenary sessions and conferences. All of the presented data and analysis of Belgrade as a tourist destination shows to us that there is a strong link between characteristics of tourist demand and hotel sector development in Belgrade.

\section{Conclusion}

The data presented in this paper shows to us that hotel sector in Serbia and Belgrade is experiencing certain changes in number, structure and target market they intend to service. These changes are especially present in Belgrade as a leading tourist destination in Serbia. Major changes are in rising number of new hotels and structural changes inside hotel sector with higher participation of four and five stars hotels, than it was the case in the beginning of this century. Several reasons influenced present trends in hotel sector in Belgrade. The first reason is a change in ratio of domestic and foreign tourists. While domestic tourists had dominant position amongst overall tourists at the beginning of the 21 st century nowadays the dominant group are foreign tourists who are two and a half times greater in number than domestic tourists. The other crucial trend present on Belgrade tourist market is that the majority of tourists who visited Belgrade are here for business reasons.

The described trends influenced the contemporary directions of development of hotel sector in Belgrade. Two or three major trends can be identified. The first one is that almost all new and renovated hotels consider business tourists as their target market. The second one is that such market orientation has led to development of meeting and convention capabilities of hotels which today present significant asset in the future development of business tourism in Belgrade. And the third major trend is strengthening the position of international hotel chains which will increase their presence on the market through increasing the number of hotels of already present hotel chains and through the entrance of new hotel chains. It can be assumed that the presented trends in tourist characteristics and hotel development will continue in next mid time period. 


\section{Bibliography}

Bernini C. (2009): Convention industry and destination clusters: Evidence from Italy, Tourism Management Vol. 30, pp. 878-889.

Davidson R., Cope B. (2003): Business travel - Conferences, Incentive Travel, Exhibitions, Corporate hospitality and Corporate Travel, Prentice Hall, London.

Hotel guide (2015), Hores - Business association of hotel and restaurant industry, Belgrade.

Jerković S. (2009): Razvoj evropskih urbanih turističkih sistema, Bulletin of the Serbian Geographical Society LXXXIX (1), Serbian Geographical Society, Belgrade, pp. 21-30.

Kosar Lj. (2008): Obim i struktura hotelijerstva Srbije u kontekstu budućeg razvoja, Conference Proceedings - Hotelska kuća 2008, Zlatibor.

Meetings and Conventions - Planner's Guide 2009/10 (2010), Belgrade Convention Bureau - Tourist organization of Belgrade, Belgrade available at www.tob.co.rs.

Pavlović T. (2008): Ulazak međunarodnih hotelskih lanaca u našu zemlju i region, Conference Proceedings - Hotelska kuća 2008, Zlatibor, pp. 147-154.

Serbia meeting planner's guide 2011 (2011), Serbia Convention Bureau, Belgrade available at www.scb.travel.

Statistical Yearbook of Belgrade 2013 available at https://zis.beograd.gov.rs.
Statistical Yearbooks of Serbia 2000-2014 available at $h t t p: / / w e b r z s . s t a t . g o v . r s$.

Strategy of tourism development of Belgrade (2008), Institute of economic sciences, Belgrade.

Šimičević D. (2009): Konvencije i konferencije - deo sektora poslovnog turizma u porastu (Conventions and Conferences - The part of Business Tourism sector on the increase), Turističko poslovanje 4, The College of Tourism, Belgrade, pp. 111-118.

Šimičević D. (2011): Mesto specifičnih prostora u održivom razvoju gradskih turističkih centara na primeru Beograda (The position of specific areas in sustainable development of city break destinations in the case of Belgrade), Turističko poslovanje 7, The College of Tourism, Belgrade, pp. 105-111.

Štetić S. (2007): Posebni oblici turizma, Author, Belgrade.

The International Association Meetings Market 2000-2009 - abstract for non members (2010), International Congress and Convention Association (ICCA), Amsterdam.

The International Association Meetings Market 2014 - Abstract for international associations, press, universities, students, and consultants (2015), International Congress and Convention Association (ICCA), Amsterdam.

https://zis.beograd.gov.rs

www.merr.gov.rs (15. februar 2014)

www.scb.travel (1. octobar 2015)

www.tob.co.rs (15. november 2015) 